\title{
GARŚĆ UWAG O POTRZEBIE OPTYMALIZACJI KOMUNIKACJI MIĘDZY TLUMACZAMI PRZYSIEGLYMI A PRZEDSTAWICIELAMI ORGANÓW ŚCIAGANIA, SPOSOBACH JEJ OSIĄGNIĘCIA I POTENCJALNYCH KORZYŚCIACH
}

\author{
Lech ZIELIŃSKI, dr hab. prof. UMK \\ Uniwersytet Mikołaja Kopernika w Toruniu \\ Katedra Filologii Germańskiej, Bojarskiego 1, 87-100 Toruń \\ e-mail: proflechzielinski@gmail.com
}

\begin{abstract}
Abstrakt: Autor współpracuje na co dzień z przedstawicielami organów ścigania zarówno w zakresie wykonywania tłumaczeń poświadczonych, jak i tłumaczeń ustnych. Artykuł stanowi dokładną analizę dwóch przypadków obszernych zleceń tłumaczeniowych, podczas których podjęto próbę optymalizacji zakresu przekładu w celu zaoszczędzenia czasu pracy thumacza i środków publicznych. Autor wychodzi z założenia, że proces realizacji dużych zleceń tłumaczeniowych na rzecz organów państwa, a w szczególności na rzecz prokuratury, nie (zawsze) przebiega w sposób optymalny. Ustala przyczyny takiego stanu rzeczy i sugeruje, co poprawić, by spowodować większą optymalizację w tym zakresie, w szczególności w odniesieniu do obszernych tłumaczeń. Ponieważ oba opisane przypadki różnią się pod względem skuteczności działania podjętego w celu optymalizacji, kierunek analiz jest nieco inny, a wyciągnięte wnioski są komplementarne. Podczas gdy w pierwszym przypadku przeszkodą w skutecznej komunikacji między thumaczem a przedstawicielami organów ścigania jest rola pośrednicząca prokuratur okręgowych w przypadku kierowania wniosków o pomoc prawną, ograniczająca w znacznym stopniu możliwość kontaktu thumacza z osobą, dla której thumaczenie jest wykonywane, źródeł problemu w drugim przypadku autor dopatruje się w zapisie ustawy z 25 listopada 2004 r. o zawodzie tłumacza przysięgłego, a dokładniej w jej art. 13. Wnioski mają charakter praktyczny, a ich wdrożenie może przyczynić się do poprawy komunikacji między tłumaczami przysięgłymi a organami ścigania, do efektywniejszego wydawania środków budżetowych oraz przyspieszenia postępowań.
\end{abstract}

Słowa kluczowe: thumacz przysięgły, optymalizacja komunikacji, przedstawiciele organów ściagania, thumaczenie prawne i prawnicze 
Lech Zieliński: Garść uwag o potrzebie ...

\author{
A HANDFUL OF REMARKS ON THE NECESSITY FOR COMMUNICATION \\ OPTIMIZATION BETWEEN SWORN TRANSLATORS AND LAW ENFORCEMENT \\ BODIES, FOR THE DEVELOPMENT OF STRATEGIES FOR ITS ACHIEVEMENT AND \\ POTENTIAL BENEFITS
}

\begin{abstract}
The author has been regularly cooperating with law enforcement bodies in the field of sworn translation and interpreting. The article is a thorough analysis of two extensive translation commissions, during the performance of which an attempt was made at the optimization of the translation process to save the translator's time and public funds. The author assumes that completion of extensive translation services delivered for the Public Prosecutor's Office is not always optimal. The author gives reasons for this situation and offers potential solutions aimed at the improvement and optimization of the work on more extensive translations. Due to the fact that both these cases differ in terms of efficiency of actions aimed at the optimization of the process, analytical criteria slightly differ, yet conclusions drawn are complementary. In the first case, an obstacle for effective communication between the translator and law enforcement bodies is the intermediary role of district prosecutor's offices while applying for legal assistance, which substantially restricts the possibility of the translator contacting the person for whom translation is provided. The source of problems in the second case can be found in provisions of the Act of 25 November 2004 on the Profession of Sworn Translator, and specifically in Article 13. Conclusions are of a more practical nature, and their implementation can contribute to the improvement of communication between sworn translators and law enforcement bodies, to more effective spending of public funds and accelerating proceedings.
\end{abstract}

Key words: sworn translator, communication optimization, law enforcement bodies, legal translation

Hominibus natura prodesse iubet. Lucius Anneus Seneka, Ad Gallionem de vita beata XXIV, 2

\title{
Wprowadzenie
}

Niniejszy artykuł zawiera wnioski, które pojawiły się podczas wykonywania przeze mnie pracy thumacza, a w szczególności przemyślenia związane z wykonywaniem thumaczeń na zlecenie Prokuratury Okręgowej w Bydgoszczy, z którą współpracuję od 2011 r. Podstawowym pytaniem, na które szukam odpowiedzi, jest kwestia, w jaki sposób osiągnąć optymalizację w zakresie określenia przedmiotu zlecenia w przypadku bardzo obszernych tlumaczeń, wymagających dużych nakładów środków publicznych oraz wielu godzin pracy tłumacza. Wychodzę z założenia, że warunkiem sine qua non jest skuteczna komunikacja między przedstawicielem organu państwa, który $\mathrm{z}$ danego tłumaczenia będzie korzystał, i tłumaczem. Takie postawienie problemu wynika 
z przyjętej hipotezy, wysuniętej w oparciu o własne doświadczenie, wedle której proces realizacji dużych zleceń tlumaczeniowych na rzecz organów państwa, a w szczególności na rzecz prokuratury, nie (zawsze) przebiega w sposób optymalny. Przyczyn takiego stanu rzeczy jest wiele i nie wszystkie dadzą się sprowadzić do niedostatecznej komunikacji.

Przedmiotem podlegającym dokładnej analizie są dwa obszerne zlecenia thumaczeniowe wykonane przeze mnie na rzecz prokuratury okręgowej w roku 2013 (3 Ds 1197/11, sygn. wewn. Oz 9/12) oraz w 2014 (VI Ds 54/11). Sprawy te są dla niniejszego badania bardzo ciekawe, gdyż w obu przypadkach podjęto próby optymalizacji zlecenia $\mathrm{w}$ drodze ograniczenia jego zakresu. Za każdym razem też organem nadzorującym postępowanie nie była prokuratura okręgowa, co jest o tyle istotne, że w takiej sytuacji komunikacja między przedstawicielem organu, dla którego tłumaczenie jest wykonywane, a tłumaczem jest zawsze utrudniona, o czym będzie mowa niżej. W jednym i drugim przypadku chodziło o przekład na język polski (z języka niemieckiego) materiałów przesłanych przez stronę niemiecką w ramach realizacji wniosku o pomoc prawną. Podjęte kroki różnią się jednak pod względem osiągniętego skutku oraz strony inicjującej optymalizację zlecenia. Wspomniane różnice umożliwiają wyciągnięcie ciekawych wniosków i uogólnień. Dla zobrazowania tych wstępnych informacji posłużmy się tabelą:

\begin{tabular}{|c|c|c|c|c|c|}
\hline $\begin{array}{l}\text { Thumaczenie } \\
\text { w sprawie }\end{array}$ & $\begin{array}{c}\text { Organ } \\
\text { zlecający } \\
\text { tlumaczenie }\end{array}$ & $\begin{array}{c}\text { Organ } \\
\text { nadzorujący } \\
\text { sprawę }\end{array}$ & $\begin{array}{c}\text { Strona } \\
\text { inicjująca } \\
\text { optymalizację } \\
\text { zlecenia }\end{array}$ & $\begin{array}{c}\text { Skuteczność } \\
\text { podjętego } \\
\text { działania }\end{array}$ & $\begin{array}{c}\text { Objętość } \\
\text { thumaczenia } \\
\text { / } \\
\text { Oszczędność }\end{array}$ \\
\hline Oz 9/12 & $\mathrm{PO}$ & PR & tłumacz & nieskuteczne & 238 s. / brak \\
\hline VI Ds 54/11 & $\mathrm{PO}$ & $\mathrm{ABW}$ & $\mathrm{ABW}$ & skuteczne & $\begin{array}{c}81 \text { z } 354 \text { s. / } \\
77 \%\end{array}$ \\
\hline
\end{tabular}

Weryfikacja tezy roboczej w odniesieniu do pierwszej (nieskutecznej) próby optymalizacji zlecenia thumaczenia, wedle której przyjęto, że część przetłumaczonych dokumentów nikomu nie była potrzebna i że doszło do zbędnego wydania środków publicznych i marnotrawstwa czasu tłumacza ${ }^{1}$, wymagała przeprowadzenia dodatkowych badań mających na celu ustalenie stopnia przydatności przetłumaczonych dokumentów. Przedmiotowe badanie zainicjowałem pismem z 17 stycznia 2014 r. skierowanym do Prokuratury Okręgowej w Bydgoszczy zawierającym prośbę o umożliwienie kontaktu

\footnotetext{
${ }^{1}$ Zakładam tu może naiwnie, iż każdy tłumacz chce wierzyć, że wykonuje pracę, która jest komuś choć w niewielkim stopniu przydatna. Zakładam również, że świadomość robienia rzeczy zbędnych ma negatywny wpływ na motywację i na jakość tłumaczenia.
} 
z prokuratorem z Prokuratury Rejonowej nadzorującym postępowanie, na potrzeby którego thumaczenie było wykonane. W odpowiedzi z 20 stycznia 2014 r. otrzymałem zgodę na jego przeprowadzenie, oraz dane kontaktowe osoby z prokuratury rejonowej. Samo badanie miało miejsce ostatecznie (po ustaleniu terminów, przesłaniu ankiety itd.) w maju 2014 r., kiedy to otrzymałem wypełnioną ankietę i przeprowadziłem półgodzinny wywiad z prokuratorem. Ponieważ wyniki tego badania zostały przedstawione $w$ formie referatu ${ }^{2}$, a następnie opublikowane (Zieliński 2014), nie będę w tym miejscu powielał prezentowanych wcześniej treści, a jedynie streszczę najważniejsze ustalenia i przedstawię wysunięte wnioski. Nie można bowiem zakładać, że wystarczy tutaj odesłać czytelnika do właściwej publikacji, gdyż artykuł został napisany w języku niemieckim, co w warunkach polskich ogranicza liczbę jego odbiorców. Drugim elementem ogranicząącym potencjalną liczbę odbiorców jest bardzo ograniczona dostępność publikacji w Polsce. Moje refleksje w odniesieniu do drugiego przypadku są w niniejszym artykule prezentowane po raz pierwszy. Można uznać go zatem za rozwinięcie i kontynuację wspomnianego wyżej pilotażowego projektu. Warto zaznaczyć, że występuje jeszcze jeden ważny związek między pierwszą nieudaną próbą optymalizacji zakresu przedmiotu thumaczenia a drugą, zakończoną sukcesem. Wnioski wyciągnięte z przeprowadzonych badań miały wyłącznie charakter hipotetyczny, wskazywały jedynie potencjalne obszary optymalizacji współpracy i redukcji kosztów, podczas gdy drugi przypadek dostarczył danych empirycznych potwierdzających wcześniejsze hipotezy. Konkretne działania doprowadziły bowiem do redukcji kosztów thumaczenia o około 70\%. Przypadek ten można postrzegać zatem jako pozytywną weryfikację wyciągniętych wcześniej wniosków i potwierdzenie zasadności stawianych postulatów.

\section{Stan badań, uwagi metodologiczne}

W Polsce nie prowadzono jeszcze badań w tym zakresie. Tłumacze wprawdzie często podczas konferencji i w publikacjach zwracają uwagę na konieczność poprawy współpracy i komunikacji między tłumaczami i organami

\footnotetext{
${ }^{2}$ Referat przedstawiłem przed zakończeniem badania na międzynarodowym kongresie zorganizowanym przez Polskie Towarzystwo Thumaczy Przysięgłych i Specjalistycznych TEPIS w Krakowie w dniach 3-5 kwietnia 2014 roku, a problemem podzieliłem się również po jego zakończeniu na szkoleniu zorganizowanym przez Dolnośląskie Koło tego towarzystwa we Wrocławiu 9 maja 2014 r.
} 
państwowymi, jednak odnoszą się do trochę innych obszarów i wyrażają przede wszystkim własne oczekiwania. Przykładem może być artykuł Artura D. Kubackiego (2014) Ttumacz przysięgly w polskim systemie wymiaru sprawiedliwośc, w którym jedną część poświęcono współpracy thumaczy przysięgłych z organami ścigania i wymiaru sprawiedliwości (por. 5860). Autor wymienił łącznie 12 punktów o bardzo różnej wadze dotyczących tej współpracy, przy czym niektóre postulaty co najwyżej wskazują na złe praktyki, bo zawarte $\mathrm{w}$ nich treści są $\mathrm{w}$ świetle obowiązującego prawa uregulowane ${ }^{3}$. Kilka z nich, jak zadbanie o dobrą jakość kopii w przypadku zlecenia tłumaczenia $\mathrm{z}$ kopii (5), dostosowanie tempa wypowiedzi osób na sali sądowej do możliwości tłumacza (6), zaplanowanie odpowiednio dłuższego czasu na rozprawę z udziałem tłumacza (9), umożliwienie tłumaczowi dobrej słyszalności na sali sądowej (10) dotyczą kwestii czysto technicznych. Za postulat utopijny należy uznać punkt 11, w którym autor sugeruje zadbanie o to, aby formułowane przez pracowników policji, prokuratury i sądów komunikaty były na tyle jasne i precyzyjne, by thumacz mógł je zrozumieć i przełożyć na język obcy, a w przypadku tekstów pisanych - by teksty te były starannie zredagowane i nie zawierały między innymi błędów interpunkcyjnych, utrudniających zrozumienie dokumentów (por. Kubacki 2014: 59). Kubacki, jak się wydaje, chciałby działać w świecie idealnym, wolnym od błędów oraz dwu- lub wieloznaczności, w świecie jednoznacznych sformułowań. Problem polega tylko na tym, że takiego świata nie ma i zważywszy na ułomność natury ludzkiej być nie może, a thumacz działa zawsze $\mathrm{w}$ określonych realiach $\mathrm{i}$ musi się $\mathrm{z}$ nimi skutecznie zmierzyć. Błędy więc występowały i będą występować zarówno w tekstach podlegających tłumaczeniom, jak i w samych tłumaczeniach ${ }^{4}$. Zresztą sam postulat uwidacznia nieodpowiedni stopień komunikacji między tłumaczem a organami państwowymi, bo jeżeli tłumacz znajdzie w przekazanym do

\footnotetext{
${ }^{3}$ Chodzi tu na przykład o umożliwienie thumaczowi wglądu do akt przed rozprawą w celu przygotowania się językowo-terminologicznego. Pomijam $w$ tym miejscu fakt, że z przedstawionego postulatu wynika, że chodzi o etap postępowania sądowego, w którym generalnie dostęp do akt jest dużo prostszy niż w postępowaniu przygotowawczym. Art. $198 \S 1$ k.p.k. gwarantuje biegłym w uzasadnionych przypadkach dostęp do akt w zakresie niezbędnym do wydania opinii, a art. $204 \S 3$ k.p.k. stanowi, że do tłumaczy stosuje się odpowiednio przepisy dotyczące biegłych. Zatem z art. $198 \S 1$ w zw. z art. $204 \S 3$ k.p.k. wynika, że thumacze mają dostęp do akt, jeżeli jest taka potrzeba, chociaż decyzje w tym zakresie rzeczywiście nie są spójne, por. A. Mendel (2011: 40), dostęp 10 września 2015 r. http://www.tepis.org.pl/pdf-doc/home//rjtpk.pdf.

${ }^{4} \mathrm{~W}$ tym miejscu należy wskazać na problem hierarchizacji błędów w tłumaczeniach, na który zwróciła ostatnio uwagę J. Dybiec-Gajer (2013: 183-186) Czym innym jest bowiem błąd krytyczny, zmieniający sens kluczowego miejsca oryginału, a czym innym literówka czy błąd językowy.
} 
tłumaczenia tekście ewidentne błędy, to przecież może zadzwonić do zleceniodawcy i sprawę wyjaśnić, a w przypadku thumaczenia ustnego dopytać, co nadawca miał na myśli. Na podstawie wieloletniego doświadczenia mogę stwierdzić, że w obszerniejszych tekstach przekazanych do tłumaczenia (powyżej 5 stron) błędy są raczej regułą niż wyjątkiem, i to zarówno w dokumentach powstałych w Niemczech, jak i w Polsce, w szczególności tych powstających na etapie postępowania przygotowawczego. Zresztą nie chodzi tutaj o krytykę wymienionych postulatów, a jedynie o pokazanie, że artykuł Kubackiego dotyczy innego problemu niż ten poruszany w niniejszym tekście.

Kolejnym przykładem może być Raport $z$ badania ankietowego na temat jakości tlumaczeń $w$ postępowaniu karnym opracowany przez Annę Mendel z Krajowej Szkoły Sądownictwa i Prokuratury na podstawie reprezentatywnych badań ankietowych. Został $\mathrm{w}$ nim również przedstawiony problem współpracy tłumaczy z przedstawicielami wymiaru sprawiedliwości w kontekście jakości tłumaczenia (s. 39-40). Do czynników mających negatywny wpływ na jakość tłumaczenia tłumacze zaliczyli ograniczoną możliwość zapoznania się z aktami sprawy przed wykonaniem thumaczenia ustnego $(50 \%$ sędziów bądź prokuratorów nie wyraża zgody na udostępnienie thumaczowi akt w celu przygotowanie się do tłumaczenia). Ten i inne opisywane problemy (akustyka sali sądowej, niewłaściwe umiejscowienie tłumacza) dotyczą głównie tłumaczeń ustnych oraz przygotowania się do nich, niezwiązanych $\mathrm{z}$ przedmiotem prezentowanej analizy.

W przypadku oparcia badań na szczegółowej analizie dwóch konkretnych przypadków zawsze musi pojawić się pytanie o ich reprezentatywność, a co za tym idzie o zasadność wybranej metody badawczej. Metoda studium przypadku (case study) jest wprawdzie stosowana w nauce, w szczególności w krajach anglosaskich, niemniej pozostaje ona metodą sporną, gdyż waga stwierdzeń wyciągniętych z badań przeprowadzonych przy jej użyciu może być kwestionowana ${ }^{5}$. Również sposób i jakość komunikacji między Prokuraturą Okręgową w Bydgoszczy a tłumaczami przysięgłymi, stanowiący przedmiotową ramę przeprowadzonych badań, nie są $\mathrm{z}$ pewnością reprezentatywne dla wszystkich organów ścigania w Polsce. Zauważyć jednak należy, że przeprowadzenie szerszych badań może okazać się dość problematyczne, bo raczej nikt nie będzie skłonny przyznać $\mathrm{w}$ badaniu ankietowym abstrahującym od konkretnych przypadków, że jakiś obszar niezbyt dobrze funkcjonuje i że środki publiczne wydawane są w sposób nieracjonalny. Ze względu na niedoskonałość metodologiczną przeprowadzonych badań należy

\footnotetext{
${ }^{5} \mathrm{Na}$ temat samej metody por. R. K. Yin (2009), na temat mocy wyjaśniającej hipotez: A. Grobler (2006: 120-133).
} 
stwierdzić, że część wyciągniętych wniosków nie pozwala na szersze uogólnienia. Niemniej tam, gdzie dostrzegam problem w rozwiązaniach systemowych lub ustawowych, wnioski natury ogólnej są jak najbardziej zasadne.

\section{Wnioski płynące $z$ badania stopnia przydatności przetlumaczonych dokumentów}

Jak wspomniano wyżej, w badaniu przeprowadzono szczegółową analizę jednostkowej sytuacji komunikacyjnej związanej $\mathrm{z}$ wykonaniem bardzo obszernego thumaczenia (łącznie 238 stron thumaczeniowych), w czasie którego po przeanalizowaniu wszystkich dokumentów zwróciłem się do prokuratora z sugestią przejrzenia ich i podjęcia decyzji odnośnie do ograniczenia zakresu zlecenia. Wydawało mi się bowiem, że nie było zasadne tłumaczenie wszystkiego, na przykład dokumentów dotyczących zwrotu kosztów stawienia się świadków w procesie toczonym przed niemieckim sądem, rozliczeń między sądem a kancelarią adwokacką itd., czyli tych, które można określić jako niemieckie dokumenty okołoprocesowe. Prokurator stwierdził wówczas, że on nie prowadzi sprawy, więc tego typu decyzji podejmować nie może, i polecił tłumaczenie wszystkiego zgodnie $\mathrm{z}$ treścią postanowienia $\mathrm{w}$ przedmiocie wezwania tłumacza. Ponieważ jako tłumacz przysięgły nie wiedziałem, co było istotne dla sprawy, gdyż nie miałem żadnego kontaktu $\mathrm{z}$ osobą, do której ostatecznie moje tłumaczenie trafiło ${ }^{6}$, konieczne było przeprowadzenie badania post factum. Prowadzący sprawę prokurator otrzymał mailem ankietę (załącznik 1), którą wypełnił, a w momencie jej przekazania udzielił również wywiadu. Jednoznaczna interpretacja wyników ankiety jest dość problematyczna, gdyż podane w niej dane nie były spójne. Podczas gdy w ogólnej ocenie stopnia przydatności przetłumaczonych dokumentów zakreślono przedział powyżej 75\% (w pierwszej rozmowie telefonicznej było to około 50\%), stopień przydatności

\footnotetext{
${ }^{6} \mathrm{Sam}$ fakt braku kontaktu thumacza $\mathrm{z}$ przedstawicielem organu ścigania, który ostatecznie wykorzystuje przetłumaczone dokumenty przy podejmowaniu określonych rozstrzygnięć, pokazuje w całej rozciągłości, jak wiele w tym obszarze należy ulepszyć. Oczywiście nie można twierdzić, że taka sytuacja występuje zawsze, niemniej w przypadku wniosków o pomoc prawną, które w realiach polskich wysyłane są za pośrednictwem prokuratury okręgowej, często tak się dzieje, zwłaszcza wówczas, gdy sprawę prowadzi prokuratura rejonowa. Tłumacz bowiem jest powoływany $\mathrm{w}$ takich wypadkach przez prokuraturę okręgową i jedynie $\mathrm{z}$ nią kontaktuje się w czasie realizacji zlecenia.
} 
podanych w tabeli wybranych dokumentów w skali ${ }^{7}$ od 0 do 10 oceniono bardzo nisko (średnia 1,78). Stopień przydatności 8 z 13 dokumentów, którym przyporządkowano jaką́s wartość (dwa pola pozostały niewypełnione), oceniono na 0 lub 1, trzy kolejne na 2. Tylko dwóm dokumentom przyporządkowano wyższą wartość (pkt 3 i 7 w tabeli). Można zatem $\mathrm{z}$ dużym prawdopodobieństwem stwierdzić, że wstępna ocena stopnia przydatności miała charakter odpowiedzi dyplomatycznej, co potwierdzają ostatnie dwa punkty ankiety, w których uznano, że tłumaczenie części dokumentów było zbędne. W ostatnim punkcie okazało się, że prokurator nie zleciłby tłumaczenia $13 \mathrm{z} 15$ wymienionych dokumentów, co oznacza, że w tym miejscu ocenił stopień ich przydatności na około $13 \%$. Taki stan rzeczy potwierdził przeprowadzony wywiad, w którym w komentarzu do oceny przydatności thumaczeń dokumentów określonych w tabeli padły następujące słowa: „Jeżeli chodzi o przydatność tych materiałów $\mathrm{w}$ tabeli do rozstrzygnięcia problemu, o którym wcześniej rozmawialiśmy, [...] to przydatność, powiedziałabym, była prawie żadna, należało by spojrzeć prawdzie w oczy"8. Również w rozmowie wstępnej, podczas której wyjaśniono mi cel wniosku o pomoc prawną, prokurator zauważył, że dla podjęcia ostatecznej decyzji kluczowy okazał się jeden dokument. Ta wypowiedź pozwala na wyciągnięcie jednoznacznej konkluzji, że znacznej części poniesionych nakładów można było uniknąć. Warunkiem koniecznym byłaby oczywiście skuteczna komunikacja między tłumaczem a osobą korzystającą z jego pracy, umożliwiająca podjęcie decyzji odnośnie do ostatecznego zakresu przedmiotu tłumaczenia. Pomijam w tym miejscu kwestię długiego czasu postępowania, bo oprócz poniesionych przez budżet państwa kosztów przekład wszystkich dokumentów trwał prawie dwa miesiące, a poszkodowany, choć sprawa nie należała do trudnych, musiał długo czekać na odbiór zabezpieczonego w Polsce pojazdu.

Jednym z najważniejszych wniosków wyciągniętych w artykule opisującym tę sprawę było wskazanie na fakt, że brak komunikacji między tłumaczem a przedstawicielem organu ścigania, dla którego tłumacz pracuje, wynika z tego, iż w zdecydowanej większości spraw pośredniczą prokuratury okręgowe. Przekazywanie wniosków o pomoc prawną jest uregulowane w art. 6

\footnotetext{
${ }^{7}$ Wartość najniższa (0) oznaczała, że thumaczenie było niepotrzebne, zaś najwyższa (10), że absolutnie konieczne (por. Zieliński 2014: 221).

${ }^{8}$ Cytowane słowa padły w czwartej minucie nagrania. Tworząc zestaw dokumentów do oceny, wybrałem takie, co do których sądziłem, że ich przydatność jest duża lub bardzo duża oraz takie, których przydatność wydawała mi się wątpliwa. Z powyższego wynika, że właściwa wstępna ocena przydatności nadesłanych dokumentów w języku obcym możliwa jest jedynie we współpracy tłumacza z osobą prowadzącą daną sprawę, a do tej niezbędna jest komunikacja.
} 
Konwencji o pomocy prawnej $\mathrm{w}$ sprawach karnych między państwami członkowskimi Unii Europejskiej sporządzonej w Brukseli dnia 29 maja 2000 r. Choć daje on dość dużą swobodę w konstelacji organów przekazujących wnioski o pomoc prawną, powierzając organom centralnym jedynie sprawy najważniejsze, to jednak $\mathrm{w}$ Polsce organem pośredniczącym $\mathrm{w}$ ich przekazywaniu są $\mathrm{W}$ zasadzie prokuratury okręgowe, nadzorujące jedynie niewielką część postępowań, w ramach których kierowany jest wniosek o pomoc prawną. W przypadku gdy organem nadzorującym dane postępowanie nie jest prokuratura okręgowa, kontakt i skuteczna komunikacja między tłumaczem a organem ścigania nadzorującym postępowanie może w ogóle nie występować, co znacznie utrudnia lub uniemożliwia optymalizację zakresu zlecenia. W konkluzji stwierdziłem, że w przypadku obszernych zleceń thumaczeniowych należy systemowo umożliwić thumaczowi kontakt $\mathrm{z}$ organem nadzorującym sprawę, by przez optymalizację zakresu zlecenia ograniczyć koszty thumaczenia i skrócić czas potrzebny na jego wykonanie (por. Zieliński 2014: 224) ${ }^{9}$. Wprowadzenie w całej Polsce procedury konsultacji między thumaczem a organem korzystającym $\mathrm{z}$ jego pracy w przypadku zleceń o dużej objętości, z którymi w przypadku realizacji wniosków o pomoc prawną niekiedy mamy do czynienia, przyniosłoby w skali kraju znaczne oszczędności. Analiza drugiego przypadku pokaże jednak, że obowiązujące dziś prawo dotyczące tłumaczy przysięgłych również stanowi znaczną przeszkodę w optymalizacji współpracy.

\section{Analiza przypadku skutecznej optymalizacji zlecenia tlumaczenia uzyskanej dzięki komunikacji}

Jak wspomniano we wstępie, przedmiotem analizy drugiego przypadku jest zlecenie, w przypadku którego organ oczekujący na materiały przesłane w wyniku realizacji wniosku o pomoc prawną $\mathrm{z}$ własnej inicjatywy podjął

\footnotetext{
${ }^{9}$ Rzeczą zdumiewającą jest fakt, że w przypadku tłumaczeń, które nie są poświadczone, współpraca i komunikacja między tłumaczem a zleceniodawcą jest sprawą oczywistą, a w przypadku thumaczeń funkcjonujących $\mathrm{w}$ międzynarodowym obiegu prawnym takiej praktyki często brak. Może jedna z przyczyn takiego stanu rzeczy leży w ograniczonym uświadomieniu sobie przez tłumaczy jak i przedstawicieli organów ścigania faktu, że zarówno praca tłumacza, jak i jej późniejsze wykorzystanie mieszczą się w szeroko pojętej ramie wspólnego działania służącego osiągnięciu konkretnego celu. Jego efektywność uzależniona jest zatem od właściwej współpracy i komunikacji. Jeżeli miast holistycznego podejścia dominuje myślenie etapowe (najpierw tłumacz, potem analiza tłumaczenia, potem decyzja), konieczność współpracy wydaje się mniej oczywista.
} 
skuteczną próbę ograniczenia zakresu ich przekładu. Ponieważ temu sensownemu rozwiązaniu towarzyszyły post factum kuriozalne okoliczności, zasadne jest, by się nad całą sytuacją poważnie pochylić i wyciągnąć stosowne wnioski. Przypadek miał wprawdzie charakter jednostkowy, ale źródła problemu tkwią, jak zostanie wykazane, w treści ustawy o zawodzie tłumacza przysięgłego dotyczącej wszystkich tłumaczy, a więc potencjalnie każdego analogicznego przypadku.

\section{Opis sytuacji}

W sierpniu 2014 r. otrzymałem telefon z Prokuratury Okręgowej w Bydgoszczy z prośbą o wstępną wycenę tłumaczenia na język polski 354 kart przysłanych przez stronę niemiecką $\mathrm{w}$ ramach realizacji wniosku o pomoc prawną. Bez wglądu do dokumentów trudno o ich jednoznaczną wycenę, więc powiedziałem, że koszt może się wahać między 10000 a 130000 złotych, zaznaczając wyraźnie, że są do dane szacunkowe. We wrześniu 2014 r. odbyłem rozmowę telefoniczną z pracownikiem Delegatury ABW w Bydgoszczy, której przedmiotem była prośba o dokonanie przeglądu materiałów nadesłanych przez stronę niemiecką i sporządzenia zestawienia ich treści. Takiego przeglądu dokonałem w ciągu kilku dni i opatrzyłem go krótkim komentarzem. Po wykonaniu zadania miało miejsce podpisanie protokołu oględzin rzeczy (RSD 1111, VI DS 5411), do którego przekopiowano sporządzoną wcześniej i wysłaną drogą mailową tabelkę, a pod nią umieszczono następującą konkluzję: „Wobec powyższego, mając na uwadze wartość dowodową dla prowadzonego postępowania przygotowawczego zbioru materiałów poddanego oględzinom, należy stwierdzić, iż pełnemu tłumaczeniu na język polski należy poddać karty wskazane w powyższym zestawieniu poprzez wyróżnienie czcionki”. W trakcie czynności stwierdziłem, że poświęciłem na wykonanie prośby około 5 godzin i oczekuję wynagrodzenia w wysokości około 200 zł. Oficer ABW bez zastrzeżeń uznał przedstawiony nakład czasu pracy. Z protokołu oględzin rzeczy wynika, że podstawą prawną wykonanej czynności były art. $207 \S 1,311 \S 2$ i 4 k.p.k. zgodnie z art. $143 \S 1$ pkt 3 k.p.k. Następnie, 22 września 2014 r., zostało wydane postanowienie w przedmiocie wezwania thumacza (VI Ds. 54/11), w którym szczegółowo określono karty podlegające tłumaczeniu. W punkcie drugim prokurator postanawia udostępnić thumaczowi akta śledztwa w zakresie niezbędnym do wykonania czynności, do jakiej został wezwany, a w punkcie czwartym powierzyć funkcjonariuszom $\mathrm{ABW}$ wykonanie postanowienia 
w zakresie przygotowania i udostępnienia materiałów śledztwa wezwanemu thumaczowi. Pomijam w tym miejscu wszystkie drobiazgi zawierające informacje nie do końca zgodne z treścią wymienionych dokumentów, bo nie sam sposób działania organów państwowych jest w tym miejscu najważniejszy, lecz problem, który je implikuje. 20 października 2014 r. oddałem w Prokuraturze Okręgowej przekład dokumentów wskazanych w postanowieniu wraz z aktami sprawy oraz przedłożyłem rachunek na kwotę $2058 \mathrm{zł}$. W punkcie II rachunku wpisałem: „Dokonanie w dniach 6-9.09.2014 oględzin rzeczy (akt), zapoznanie się z ich treścią ( 354 karty) i wykonanie na tej podstawie zestawienia roboczego treści $5 \mathrm{~h}=195$ zl". 4 listopada 2014 r. otrzymałem pismo z Wydziału VII (Budżetowo-Administracyjnego) Prokuratury Okręgowej do którego dołączono odesłany rachunek. Główna jego treść sprowadzała się do zakwestionowania drugiego punktu rachunku $\mathrm{z}$ adnotacją, że przepisy dotyczące wynagrodzenia tłumaczy nie przewidują takiej formy czynności oraz stawki za nią. W tym samym czasie otrzymałem telefon $\mathrm{z}$ Prokuratury Okręgowej z propozycją znalezienia jakiegoś rozwiązania sprawy. Prokurator wiedział, że wskazane w rachunku czynności zostały wykonane i że dzięki nim możliwe były znaczne oszczędności (około 8000-10000 zł). Ponieważ proponowane rozwiązanie nie znalazło mojej aprobaty, 14 listopada 2014 r. prokurator wydał kolejne postanowienie $\mathrm{w}$ przedmiocie wezwania tłumacza $\mathrm{w}$ celu dokonania oględzin akt VI Ds 54/11 i zapoznania się z treścią 354 kart sporządzonych w języku niemieckim $\mathrm{w}$ terminie bez zbędnej zwłoki. Ponieważ wskazana czynność została już uprzednio wykonana, przedłożyłem w tym samym dniu rachunek na kwotę 194,36 zł (6,5 h) z następującym opisem: „Dokonanie oględzin rzeczy (akt) przez zapoznanie się $\mathrm{z}$ ich treścią (354 karty sporządzone $\mathrm{w}$ języku niemieckim) oraz wykonanie na tej podstawie zestawienia treści umożliwiającego określenie przedmiotu tłumaczenia". Ostatecznie sprawę zakończyło wydanie kolejnego postanowienia (z 4 grudnia 2014 r.), w którym przyznano mi wskazaną kwotę tytułem wynagrodzenia za tłumaczenie [sic!], chociaż zgodnie $\mathrm{z}$ postanowieniem byłem powołany w celu wykonania innej czynności, która zresztą miała miejsce dwa miesiące wcześniej.

Nie ulega wątpliwości, że ta sytuacja jest absurdalna ${ }^{10}$, mimo że zarówno organa państwowe, jak i tłumacz działali zupełnie racjonalnie, a przedstawiciele tych pierwszych starali się racjonalnie wydawać pieniądze z budżetu. Dlaczego zatem w pełni racjonalne działanie implikuje szereg działań pozornych i niepoważnych? Powyższa sytuacja pokazuje przecież, że skuteczna współpraca

\footnotetext{
${ }^{10}$ Może użyte tu słowo jest za mocne, ale jeżeli konsekwencją załatwienia w gruncie rzeczy błahej sprawy są działania sprzeczne z jej logiką i faktycznym stanem rzeczy, to łagodniejsze określenie byłoby eufemizmem.
} 
między organami państwowymi a thumaczami jest możliwa i że w niektórych sytuacjach pozwala na dokonanie znacznych oszczędności. Żeby zrozumieć, dlaczego na etapie rozliczenia doszło do szeregu dziwnych działań, trzeba sięgnąć do źródła problemu, jakim jest ustawa z dnia 25 listopada $2004 \mathrm{r}$. o zawodzie tłumacza przysięgłego (Dz. U. z 2004 r., Nr 273, poz. 2702) ${ }^{11}$. Skoncentruję się tu jedynie na zapisach ustawy relewantnych dla opisywanego przypadku. Art. 13 ustawy określona uprawnienia tłumacza przysięgłego:

Rozdział 3

Zasady wykonywania zawodu thumacza przysięgłego

Art. 13. Tłumacz przysięgły jest uprawniony do:

1) sporządzania i poświadczania tłumaczeń z języka obcego na język polski, z języka polskiego na język obcy, a także do sprawdzania i poświadczania thumaczeń $\mathrm{w}$ tym zakresie, sporządzonych przez inne osoby;

2) sporządzania poświadczonych odpisów pism w języku obcym, sprawdzania i poświadczania odpisów pism, sporządzonych w danym języku obcym przez inne osoby;

3) dokonywania thumaczenia ustnego ${ }^{12}$.

Ustawodawca, określając zakres uprawnień tłumacza przysięgłego, nie przewidział żadnych innych czynności poza sporządzaniem i poświadczaniem tłumaczeń z języka obcego i na język obcy wykonanych przez tłumacza lub inne osoby, sporządzaniem poświadczonych odpisów pism w języku obcym, sprawdzeniem i poświadczeniem takich pism sporządzonych przez inne osoby i dokonywaniem tłumaczenia ustnego. Tak opisany zakres uprawnień tłumacza przysięgłego utrudnia w znacznym stopniu jego współpracę z organami ścigania, gdyż jeżeli wystąpi konieczność wykonania wszelkich innych czynności, brak podstaw prawnych, które pozwoliłyby uregulować kwestię płatności za wykonaną pracę. Rozporządzenie Ministra Sprawiedliwości z dnia 24 stycznia 2005 r. w sprawie wynagrodzenia za czynności thumacza przysięgłego jest bowiem w tym względzie konsekwentne i odnosi się wyłącznie do tych czynności, które zostały określone w wymienionym wyżej artykule ustawy. Ponieważ w pracy tłumacza przysięgłego na rzecz organów państwowych w Polsce występują również inne sytuacje, w których tłumacz proszony jest o wykonanie czynności niemieszczących się w zakresie jego ustawowych uprawnień, modyfikacja tego artykułu jest nie tylko zasadna, ale i konieczna, tym bardziej, że czynności, o których mowa, są częstokroć niezbędne. Przykładem może być odsłuchanie i zapisanie materiału (transformacja pliku audio na plik

\footnotetext{
${ }^{11}$ Przepisy wspomnianej ustawy były omówione najpierw w komentarzu Grzegorza Dostatniego (2005), wydanym w Warszawie przez wydawnictwo TEPIS wraz z wejściem w życie ustawy, a następnie w książce pod redakcją B. Cieślika, L. Laski i M. Rojewskiego (2010), Egzamin na tlumacza przysięgłego. Komentarz, teksty egzaminacyjne, dokumenty, wyd. 2, Warszawa 2014 (wyd. 1: 2010).

${ }^{12}$ Szczegółowy komentarz do tego artykułu (por. B. Cieślik et. al. 2014: 43-46).
} 
tekstowy), a następnie dokonanie tłumaczenia jego treści. Przecież odsłuchiwanie takiego materiału (w języku obcym) i zapisanie go na papierze może być warunkiem wstępnym późniejszego tłumaczenia, ale samo tłumaczeniem nie jest. Wymieniony typ materiałów dowodowych nie jest przykładem abstrakcyjnym, gdyż w przypadku walki z przestępczością transgraniczną, a przede wszystkim z międzynarodowymi grupami przestępczymi (przemyt narkotyków itd.), wartość dowodowa uzyskanego materiału dźwiękowego odgrywa często kluczową rolę w postępowaniu.

\section{Non verbis, sed actis}

Karl Edward Weick w swojej teorii komunikacji, a w szczególności tej jej części, która opisuje rolę działania (enactment), przywiązuje dużą wagę do aktywnego komunikowania i podejmowania czynności, z których zawsze musi coś wyniknąc $c^{13}$. Rozpocząłem zatem aktywniejsze niż dotychczas działanie ponieważ ustawa o zawodzie thumacza przysięgłego od wielu lat jest przedmiotem mniej lub bardziej zasadnej krytyki, pod koniec 2014 r. zainicjowałem przy współudziale Dyrektora Wydziału Tłumaczy Przysięgłych w Departamencie Zawodów Prawniczych i Dostępu do Pomocy Prawnej (Ministerstwo Sprawiedliwości) Bolesława Cieślika i profesora Uniwersytetu Pedagogicznego w Krakowie Artura Kubackiego projekt naukowy 10 lat ustawy o zawodzie tlumacza przysięgłego, 10 lat działalności Państwowej Komisji Egzaminacyjnej. Próba krytycznego bilansu ${ }^{14}$. Jego celem jest krytyczne podsumowanie funkcjonowania ustawy o zawodzie thumacza przysięgłego oraz przedstawienie działalności PKE, postawienie stosownych diagnoz stanu obecnego oraz zaproponowanie lepszych rozwiązań na przyszłość. Do udziału w nim zaprosiliśmy prawników, członków PKE i jej konsultantów, tłumaczy, reprezentujące ich stowarzyszenia, przekładoznawców oraz wszystkich zainteresowanych tą problematyką.

Niezależnie od wspomnianej inicjatywy 21 lipca 2015 r. minister sprawiedliwości podpisał zarządzenie w sprawie powołania zespołu do przeglądu i oceny funkcjonowania ustawy o zawodzie thumacza przysięgłego. W jego skład weszli również autorzy wspomnianego projektu. 22 września 2015 r. odbyło się pierwsze spotkanie, na którym miałem okazję przedstawić problemy wynikające

\footnotetext{
${ }^{13}$ Zwięzły opis patrz Griffin 2003, rozdz. 17.

${ }^{14}$ Patrz: http://www.home.umk.pl/ lechziel/teaching/10\%20lat\%20ustawy.pdf.
} 
z art. 13 ustawy i zaproponować zmianę. Propozycja dopisania punktu czwartego do tego artykułu, który uwzględni możliwość wykonania przez tłumacza przysięgłego na żądania organów państwowych i samorządowych innych czynności okołotłumaczeniowych ${ }^{15}$, rozliczanych godzinowo jak thumaczenia ustne, znalazła wstępną aprobatę $\mathrm{u}$ wszystkich członków zespołu. Jej wprowadzenie umożliwi usprawnienie komunikacji i współpracy nie tylko między tłumaczami a przedstawicielami organów ścigania, lecz również między tłumaczami a sądami i innymi organami państwowymi i samorządowymi, zwłaszcza wtedy gdy mamy do czynienia z dużymi partiami materiału. Zarówno wykazana potencjalna możliwość znacznej redukcji kosztów w pierwszym badanym przypadku, jak i faktyczna oszczędność płynąca ze skutecznej komunikacji $\mathrm{w}$ drugim przypadku (mimo braku stosownych regulacji ustawowych) wykazały, że poprawa efektywności w tym zakresie może przyczynić się do znaczących oszczędności środków publicznych. Trudno wprawdzie oszacować, jaki jest odsetek obszernych materiałów nadesłanych w ramach realizacji wniosków o pomoc prawną wśród wszystkich materiałów, ale nawet jeżeli efektywna współpraca dotyczyłaby $10 \%$ wszystkich spraw i jeżeli przy każdej z nich oszczędności wynikające z precyzyjnego określenia zakresu tłumaczenia kształtowałyby się na poziomie $5000 \mathrm{zł}$, to w przypadku $1920^{16}$ wniosków skierowanych w 2013 r. tylko do Niemiec, otrzymalibyśmy kwotę rzędu 960000 złotych rocznie. Abstrahując od spraw czysto finansowych, poprawa komunikacji między tłumaczami a przedstawicielami organów ścigania leży w interesie jednych i drugich. Podnoszenie przeze mnie tych spraw już skutkuje określonymi działaniami w Prokuraturze Okręgowej, bo we wrześniu 2015 r. otrzymałem kolejny telefon w sprawie wspólnego przejrzenia dokumentów. Mimo braku uregulowań dotyczących czynności okołotłumaczeniowych znów tę czynność wykonam, gdyż działalność tłumacza przysięgłego to przede wszystkim służba. Ten aspekt widoczny jest również w etymologii słowa usługa. Dobrze byłoby tylko, by móc służyć w godnych warunkach.

\footnotetext{
${ }^{15}$ Określenie „czynności okołotłumaczeniowe” powstało podczas rozmowy z Arturem Kubackim we wrześniu 2015 r. w Warszawie. Można je uznać zatem za naszą wspólną propozycję.

${ }^{16}$ Sprawozdanie Prokuratora Generalnego z rocznej działalności prokuratury w 2013 r., Warszawa 2014, s. 319.
} 


\section{ZALĄCZNIK I - ANKIETA ${ }^{17}$}

Szanowna Pani Prokurator,

prowadzę badania komunikacji między thumaczami przysięgłymi a organami ścigania $\mathrm{w}$ kontekście wykonywania thumaczeń na potrzeby wspomnianych organów. Do Pani trafiło najobszerniejsze thumaczenie, wykonane przeze mnie w roku 2013. W trakcie jego wykonywania zwróciłem uwagę Prokuratorowi nadzorującemu, że niektóre dokumenty w mojej ocenie są bardzo mało przydatne w sprawie, sugerując ograniczenie zakresu tłumaczenia i tym samym przyspieszenie czasu potrzebnego na jego zrealizowanie. Pan Prokurator wyjaśnił mi wówczas, że on takiej decyzji podjąć nie może, co prawdopodobnie wynika z roli pełnionej przez Prokuraturę Okręgową w składaniu wniosków o pomoc prawną (roli pośrednika). Moje badanie służy w pierwszym rzędzie ocenie stopnia faktycznej przydatności wykonanego tłumaczenia, a jego wyniki służyć będą refleksji na temat możliwości optymalizacji w tym zakresie. Dlatego też proszę o wypełnienie poniższej ankiety zgodnie ze stanem faktycznym i własnym przekonaniem.

1. Ogólne wrażenie odnośnie do przetlumaczonych akt:

A. Zrozumialość: Czy w Pani ocenie:

a) Przetlumaczone akta byly zrozumiałe

$\square$ w całości.

$\square$ zdarzały się sporadycznie miejsca niezbyt jasne.

$\square$ czasami zdarzały się miejsca niezrozumiałe.

$\square$ często występowały miejsca niezrozumiałe.

b) Występowały miejsca w tlumaczeniach, które ogólnie były zrozumiałe, ale brak dostatecznego konteksu powodowal potrzebę dookreślenia, co autor (tłumacz) miał na myśli, jak właściwie miejsce $w$ aktach interpretować itd. W trakcie lektury

$\square$ W ogóle nie dostrzegłam takich miejsc.

$\square$ występowały takie miejsca, ale nie miały one większego znaczenia i nie było potrzeby ich doprecyzowania (wyjaśnienia).

$\square \mathrm{W}$ niektórych miejscach zastanawiałam się, jak dany fragment rozumieć.

$\square \mathrm{W}$ wielu miejscach nie byłam pewna, jak dany fragment rozumieć.

$\square$ często występowały miejsca niezrozumiałe.

\footnotetext{
${ }^{17}$ Przesłana wersja ankiety zawierała nazwiska występujących w dokumentach osób i pod tym względem różniła się od zamieszczonej.
} 
c) Czy w trakcie studiowania akt odczuwała Pani Prokurator potrzebę dopytania tlumacza o sens/kontekst określonych fragmentów przetlumaczonych dokumentów.

$\square$ W niektórych momentach odczuwałam, ale nie chciałam zawracać głowy tłumaczowi.

$\square$ Zdecydowanie nie.

$\square$ Występowały sporadycznie takie fragmenty, ale nie miały one istotnego znaczenia dla sprawy i nie warto było im więcej czasu poświęcać.

$\square \mathrm{W}$ trakcie lektury nie przyszło mi do głowy, że można w razie wątpliwości poprosić tłumacza o wyjaśnienie.

B. Kwestia uwag thumacza:

a) Czy uwagi tlumacza w nawiasach kwadratowych byly:

$\square$ przydatne w całości

$\square$ częściowo przydatne

$\square$ mało przydatne

$\square$ w całości zbędne

b) Czy częstotliwość ich występowania byla:

$\square$ odpowiednia

$\square$ występowały zbyt często

$\square$ występowały zbyt rzadko

\section{Ocena przydatności tlumaczenia}

A. Przydatność przetłumaczonych dokumentów (ocena wstępna)

a) W jakim stopniu według Pani Prokurator przetlumaczone dokumenty (jaka cześć $\mathrm{z}$ nich) były przydatne do rozpoznania badanego stanu rzeczy (rozpoznania prawdy obiektywnej) i podjęcia decyzji:

$\square$ do $25 \%$

$\square 25-50 \%$

$\square 50-75 \%$

$\square$ powyżej $75 \%$

b) Czy gdyby Pani znala w zarysie treść wszystkich dokumentów przesłanych przez stronę niemiecką, zlecilaby Pani:

$\square$ przetłumaczenie całości przesłanych akt.

$\square$ przetłumaczenie tych dokumentów, które uznałaby Pani za absolutnie niezbędne.

$\square$ przetłumaczenie tych dokumentów, które uznałaby Pani za niezbędne lub choć trochę przydatne.

B. Przydatność przetlumaczonych dokumentów (ocena szczegółowa) 


\section{a) Proszę ocenić przydatność tlumaczenia poniższych dokumentów w skali od 0 - 10, 0- całkowicie zbędne, 10 absolutnie konieczne}

\begin{tabular}{|c|c|c|c|}
\hline & Nazwa dokumentu & $\begin{array}{l}\text { Karty akt w } \\
\text { tłum. }\end{array}$ & $\begin{array}{l}\text { Ocena } \\
1-10\end{array}$ \\
\hline 1 & $\begin{array}{l}\text { Pełnomocnictwo udzielone adwokatowi H. przez } \\
\text { poszkodowanego }\end{array}$ & 16 & \\
\hline 2 & Wniosek adwokata o wgląd do akt sprawy & 17 & \\
\hline 3 & Protokół przesłuchania świadka D. & 43 & \\
\hline 4 & Wezwanie podejrzanego & 45 & \\
\hline 5 & $\begin{array}{l}\text { Zarządzenie o włączeniu adwokata G. jako } \\
\text { pełnomocnika procesowego podejrzanego }\end{array}$ & 49 & \\
\hline 6 & $\begin{array}{l}\text { Pismo adwokata z podziękowaniem dołączone przy } \\
\text { zwrocie akt }\end{array}$ & 51 & \\
\hline 7 & $\begin{array}{l}\text { Wniosek adwokata podejrzanego o umorzenie } \\
\text { posteppowania }\end{array}$ & $56 \mathrm{in}$ & \\
\hline 8 & Akt oskarżenia & 66 & \\
\hline 9 & Dowody doręczenia wezwania (świadkowie) & $\begin{array}{l}\text { Występują } \\
\text { w kilku } \\
\text { miejscach } \\
70 \text { i n. }\end{array}$ & \\
\hline 10 & Dowód doręczenia (oskarżony) & 84 & \\
\hline 11 & $\begin{array}{l}\text { Wnioski o odszkodowanie za utracony czas pracy } \\
\text { świadka oraz polecenie wypłacenie odszkodowania } \\
\text { (druga strona wniosku) }\end{array}$ & $\begin{array}{l}103 \text { i wiele } \\
\text { innych np. } \\
132 \mathrm{i} \mathrm{n.}\end{array}$ & \\
\hline 12 & $\begin{array}{l}\text { Wyciąg z rejestru działalności gospodarczej w } \\
\text { odniesieniu do świadka, który ostatecznie nie zeznawał }\end{array}$ & 134 & \\
\hline 13 & $\begin{array}{l}\text { Wniosek o ustalenie kosztów z tytułu udziału } \\
\text { adwokata }\end{array}$ & 136 & \\
\hline 14 & $\begin{array}{l}\text { Dalsze pisma w wsprawie kosztów (spór z sądem o } \\
100 \text { Euro, zakończony przyznaniem wnioskowanej } \\
\text { kwoty) }\end{array}$ & $\begin{array}{l}137,143 \\
146,148\end{array}$ & \\
\hline 15 & $\begin{array}{l}\text { Pismo Policji do Prokuratury z informacją, co } \\
\text { wprowadzono do rejestrów (ochrona danych } \\
\text { osobowych) }\end{array}$ & 150 & \\
\hline
\end{tabular}

C. Czy uważa Pani, że tłumaczenie niektórych podanych $\mathrm{w}$ tabeli dokumentów było zbędne.
$\square$ tak
$\square$ nie 
D. W przypadku odpowiedzi „tak”, proszę o wymienienie numerów zamieszczone po lewej stronie tabeli tylko tych dokumentów, których thumaczenia nie zleciłaby Pani.

Nie zleciłabym tłumaczenia dokumentów występujących w tabeli pod numerami:

\section{Bibliografia}

Dostatni, Grzegorz. 2005. Komentarz do ustawy o zawodzie tlumacza przysięgtego. Warszawa.

Cieślik, Bolesław et.al. 2010, 2014 (2). Egzamin na ttumacza przysięgłego. Komentarz, teksty egzaminacyjne, dokumenty. Warszawa.

Dybiec-Gajer, Joanna. 2013. Zmierzyć przekład? Z metodologii oceniania $w$ dydaktyce przekładu pisemnego, Kraków.

Griffin, Em 2003. Podstawy komunikacji spotecznej, Gdańsk.

Grobler, Adam. (2006). Metodologia nauk, Kraków 2006.

Kubacki, Artur, Dariusz. 2014 Tłumacz przysięgły w polskim systemie wymiaru sprawiedliwości, w: Kwartalnik Krajowej Szkoly Sąownictwa i Prokuratury 2014, z. 4 (15), s. 46-64.

Mendel, Anna 2011. Raport z badania ankietowego na temat jakości ttumaczenia $w$ postepowaniu karnym https://www.kssip.gov.pl/sites/default/files/18_8.pdf

R. K. Yin, Robert K. (2009). Case study, research design and metods, Thousand Oaks.

Zieliński, Lech. 2014: Einige Anmerkungen zu Optimierungsmöglichkeiten der Kooperation/ Kommunikation zwischen Übersetzern und polnischen Verfolgungsorganen beim Erledigen von Rechtshilfeersuchen in Strafsachen, w: Studia Translatorika 5, Wrocław 2014, s. 213-228. 